\title{
The Effect Of Intraperitoneal Bupivacaine For Post-Operative Pain Management In Patients Undergoing Laparoscopic Cholecystectomy- A Prospective Double-Blind Randomized Control Study
}

\author{
Dr. Sulekha
}

\begin{abstract}
Objective: To compare the effect of intraperitoneal bupivacaine for post-operative pain management in patients undergoing laparoscopic cholecystectomy.

Material and Methods: Group A: Patients received $20 \mathrm{ml}$ of $0.9 \%$ normal saline as placebo ( $\mathrm{n=75}$ ). Group B: Patients received $20 \mathrm{ml}$ of $0.5 \%$ Bupivacaine $(n=75)$. All patients were pre-medicated with glycopyrrolate $0.2 \mathrm{mg}$, ondansetron $4 \mathrm{mg}$ and ranitidine $150 \mathrm{mg}$ intravenously half an hour prior to induction of anesthesia. All patients were given standard general anaesthesia with propofol $(2-2.5 \mathrm{mg} / \mathrm{kg})$, fentanyl $2 \mu \mathrm{g} / \mathrm{kg}$, and succinylcholine $(2 \mathrm{mg} / \mathrm{kg})$ to facilitate tracheal intubation. Anesthesia was maintained with $60 \% \mathrm{~N}_{2} \mathrm{O}$ in oxygen with 0.5 to $1 \%$ Halothane.

Results: The age and sex distribution of both groups were similar. The heart rate, systolic \& diastolic blood pressure, mean blood pressure and mean trend of $\mathrm{SpO}_{2}$ in both groups remained similar over the periods. The mean VAS in both groups varied considerably within (between time) and between the groups (treatment) especially comparatively higher in Group A at initial hours $15 \mathrm{~min}$ to $30 \mathrm{~min}$ and at end hours 12-24 hrs as compared to $B$. On an average, the frequent dosing of rescue analgesia and mean no. of rescue analgesia doses were higher in Group A than B.

Conclusion: We conclude that intraperitoneal instillation of local anaesthetic is an easy, cheap, and noninvasive method which provides good analgesia in the immediate postoperative period after laparoscopic surgery.
\end{abstract}

Key words: Intraperitoneal Bupivacaine, laparoscopic cholecystectomy, general anaesthesia.

\section{Introduction}

Laparoscopic cholecystectomy has become a standard technique for gall bladder surgery ${ }^{1}$ (Raetzell et al 1995). There are a number of advantages to the patient with laparoscopic surgery versus an open procedure. These include reduced hemorrhage, smaller and more cosmetic incision, which reduces pain thus less pain medication, needed and shorten recovery time, thus less hospital stay and less expenditure ${ }^{2}$ (Michaloliakou et al 1996), reduced risk of acquiring infections, reduced blood loss. Patients undergoing laparoscopic procedures do experience post-operative pain, especially in the abdomen (typically a diffuse abdominal pain), back and shoulder region. Pain intensity usually peaks during the first postoperative hours and usually declines over the following two to three days ${ }^{3}$ (Alexander JI 1997). Pain after laparoscopy results from the stretching of the intra-abdominal cavity ${ }^{4}$ (Joris et al 1995), peritoneal inflammation and phrenic nerve irritation caused by residual carbon dioxide in the peritoneal cavity. Pain can prolong hospital stay and lead to increased morbidity. Intra-peritoneal injections of local anaesthetic have been proposed to minimize postoperative pain after laparoscopic surgery ${ }^{5}$.(Zmora et al 2000). Several studies have shown that visceral pain is the major component. Local anaesthetics have been administered into the peritoneal cavity during minimally invasive procedures, such as laparoscopic cholecystectomy and gynaecological laparoscopy for sterilization and $\operatorname{diagnosis}^{6}{ }^{(H e l v a c i o g l u} \mathrm{A}$ et al 1992). Hilvering et al. (2011) ${ }^{7}$ determined the effect of combined subcutaneous infiltration and intra-peritoneal instillation of levo-bupivacaine before the start of LC on postoperative abdominal pain up to $24 \mathrm{~h}$ after surgery. And they concluded that combined subcutaneous and intra-peritoneal administration of levo-bupivacaine did not influence postoperative abdominal pain after LC.

In the present study, we designed a prospective double-blind randomized control study to compare the effect of intraperitoneal bupivacaine for post-operative pain management in patients undergoing laparoscopic cholecystectomy.

\section{Material And Methods}

After getting approval from ethical Committee of King George's Medical University, UP, Lucknow, for research on human subject, written informed consent was taken from the patients selected for this study. Patients aged 20-50 years of either sex belonging to ASA physical status I or II planned for laparoscopic cholecystectomy were included in this prospective, randomized, double blind, placebo-controlled study. 
All patients were pre-medicated with glycopyrrolate $0.2 \mathrm{mg}$, ondansetron $4 \mathrm{mg}$ and ranitidine $150 \mathrm{mg}$ intravenously half an hour prior to induction of anesthesia. All patients were given standard general anaesthesia with propofol $(2-2.5 \mathrm{mg} / \mathrm{kg})$, fentanyl $2 \mu \mathrm{g} / \mathrm{kg}$, and succinylcholine $(2 \mathrm{mg} / \mathrm{kg})$ to facilitate tracheal intubation. Anesthesia was maintained with $60 \% \mathrm{~N} 2 \mathrm{O}$ in oxygen with 0.5 to $1 \%$ Halothane. Muscle relaxation was achieved with intermittent vecuronium bromide. Ventilation (tidal volume $8-10 \mathrm{ml} / \mathrm{kg}$ ) was adjusted to maintain end-tidal carbon dioxide between 34 and $40 \mathrm{~mm} \mathrm{Hg}$. Patients were placed in $15-20^{\circ}$ reverse Trendelenburg's position with left-side down tilting position. During laparoscopy, intra-abdominal pressure was limited to 10-12 $\mathrm{mmHg}$. The $\mathrm{CO} 2$ was carefully evacuated at the end of surgery by manual compression of the abdomen with open trocars. At the end of surgery, using a computer generated table of random numbers patients were randomized into one of the three groups.

Group A: Patients received $20 \mathrm{ml}$ of $0.9 \%$ normal saline as placebo $(\mathrm{n}=75)$.

Group B: Patients received $20 \mathrm{ml}$ of $0.5 \%$ Bupivacaine $(\mathrm{n}=75)$.

Drug solution was prepared by an anaesthesiologist who had not participated in the study, and drug was filled in pre-coded $20 \mathrm{ml}$ syringes. Surgeon and the anaesthesiologist in the post-anaesthesia care unit were unaware of the treatment to which each patient was randomized.

The drug was injected intra-peritoneally before the removal of trocar at the end of the surgery, in Trendelenburg's position to facilitate dispersion of drug solution in sub hepatic region. Local anaesthetic or placebo solutions were given as follows: the surgeon sprayed $10 \mathrm{~mL}$ of solution into the hepato-diaphragmatic space, $5 \mathrm{~mL}$ in the area of the gallbladder, and $5 \mathrm{~mL}$ into the space between liver and kidney. During the operation non- invasive blood pressure, heart rate, etco 2 and peripheral oxygen saturation were recorded regularly. Surgical wounds were not infiltrated with local anaesthetic solution.

Before induction of anaesthesia, the patients were instructed how to use a $100 \mathrm{~mm}$ visual analogue scale (VAS; with end point to be labelled 'no pain' and 'worst possible pain'). The degree of postoperative pain was assessed using the VAS at $15 \mathrm{~min}, 30 \mathrm{~min}, 1 \mathrm{hr}, 2,4,8,12$ and 24 hours post-operatively. Those patients had VAS $>40$, were administered a bolus of Diclofenac aqueous $(75 \mathrm{mg})$ as rescue analgesia. Ondansetron $(4 \mathrm{mg}$ i.v.) was administered on complaint of nausea and vomiting. Time to first analgesic requirement, total analgesic consumption in the first 24 hours postoperatively and occurrence of adverse events was also recorded.

\section{Analysis}

Continuous data were summarized as Mean \pm SD while discrete (categorical) in $\%$. The primary outcome measures (heart rate, systolic $\mathrm{BP}$, diastolic $\mathrm{BP}, \mathrm{MBP}$ and $\mathrm{SpO}_{2}, \mathrm{EtCo}$, and VAS) of three groups over the periods (time) were compared by repeated measures two factor (Groups and Periods) analysis of variance (ANOVA) using general linear models (GLM) followed by Tukey's post hoc test after ascertaining the normality by Shapiro-Wilk test and the homogeneity of variance by Levene's test. Groups were also compared by unpaired t-test. The discrete (categorical) variables were compared by chi-square $\left(\chi^{2}\right)$ test. A two-sided $(\alpha=2)$ $\mathrm{p}<0.05$ was considered statistically significant. All analyses were performed on STATISTICA (Windows version 6.0).

\section{Results}

The age of Group A and Group B ranged from 20-50 yrs and 28-50 yrs, respectively with mean $( \pm$ SD) $39.80 \pm 9.07 \mathrm{yrs}$ and $38.40 \pm 6.00 \mathrm{yrs}$, respectively. In both the groups, the \%age of females was higher than males and mostly with ASA grade 1 (Table-1).

The heart rate (HR) in all the three groups remained similar over the periods with slightly being higher in Group A at intra-operative periods as compared to Group B. For each time, comparing the mean HR between the groups, Tukey's test revealed significantly higher HR of Group A at intraoperative periods and 30 min of postoperative periods as compared to Group B $(\mathrm{p}<0.05)$. SBP and DBP were also remained similar over the periods in both Group A and Group B. The mean blood pressure (MBP) in all three groups remained similar over the periods with slightly being lower in Group B at all periods as compared to Group A. For each time, comparing the mean MBP between the groups, unpaired t-test test revealed significantly $(\mathrm{p}<0.01)$ lower MBP of Group B at all periods as compared to Group A (Table-2).

The mean trend of $\mathrm{SpO}_{2}$ in all three groups remained similar over the periods in both Group A and Group B. Mean $\mathrm{SpO}_{2}$ did not differed significantly (p>0.05) between Group A and Group B at all periods i.e. found to be statistically the same (Table-3). For each time, comparing the mean EtCo2 between the groups, unpaired t-test test revealed insignificant $(\mathrm{p}>0.05)$ difference in $\mathrm{EtCo} 2$ among the groups at all periods i.e. found to be statistically the same (Fig.1).

The mean VAS in both groups varied considerably within (between time) and between the groups (treatment) especially comparatively higher in Group A at initial hours 15 min to 30 min and at end hours 12-24 hrs as compared to Group B (Fig. 2). 
On an average the frequent dosing of rescue analgesia were highest in Group A followed by Group B. Further, the requirement in subjects was also highest in Group A (Table-4).

The mean no. of rescue analgesia doses of Group A $(3.84 \pm 0.75)$ was comparatively higher than both Group B $(2.12 \pm 0.33)$. Comparing the mean no. of rescue analgesia doses between the groups, unpaired t-test revealed significantly different no. of rescue analgesia doses among the groups $(\mathrm{p}<0.001)$ (Table not shown).

In both the groups, the treatment related adverse events were mostly emetic symptoms and shoulder pain with highest being in Group A. However, Hypotension, Bradycardia and Sedation were not seen. The frequency of Emetic symptoms $\left(\chi^{2}=12.32, \mathrm{p}=0.002\right)$ and shoulder pain $\left(\chi^{2}=29.55, \mathrm{p}<0.001\right)$ were significantly higher in Group A as compared to Group B (Table-5).

\section{Discussion}

Our results showed that visceral pain accounts for most of the discomfort experienced in the early postoperative period after laparoscopic cholecystectomy in Placebo group. Visceral pain developed after laparoscopic cholecystectomy was not affected by mobilization. However, coughing increased its intensity. This can be explained by that, mobilization requirescontraction of the abdominal muscles, and does not involve movement of the intra-abdominalviscera. On the other hand, cough produces an abrupt displacement of the liver, and consequently results in stimulation of the inflamed cholecystectomy wound. Also, our results showed that incisional pain is less intense than visceral pain and worsened only by coughing not by mobilization. This can be explained by that cough not mobilization causes intense abdominal muscle contraction. The postoperative pain induced by laparoscopic cholecystectomy has a considerable visceral Component (owing to surgical handling and diaphragmatic irritation by dissolved carbondioxide). At times the visceral component is such that it results in shoulder pain, similar in location and type to the pain that occurs with biliary colic. Incisional pain is less intense than visceral pain, owing to the small abdominal incisions made in the abdominal wall for the trocars and the limited damage to the abdominal wall.

Although, laparoscopic cholecystectomy is a minimallyinvasive procedure, it is associated with intraabdominal,incisional and shoulder pain after surgery. Postoperative abdominal and shoulderpain are the most common complaints after elective laparoscopiccholecystectomy. Postoperative pain is multifactorialin origin, and therefore multimodal therapy may beneeded to optimize pain relief. After laparoscopic cholecystectomy, patients complain of pain from the incision of the skin (somatic pain), of visceral pain, and of shoulder pain from diaphragm stimulation.

The irritation might be caused by localacidosis, distension of the diaphragm, or irritationsecondary to $\mathrm{CO} 2$ remaining in the abdomen. The remaining $\mathrm{CO} 2$ is a major contributor to shoulder pain is supported by investigations $^{8}$ (AlexanderJi, 1987). Pain prolongs recovery and discharge time and contributes to unanticipated admissionafter ambulatory surgery. Improved postoperative pain management using opioid-sparing regimensmay facilitate a high success rate of outpatient laparoscopic cholecystectomy ${ }^{9}$ (Bisgaard, 1999).Various techniques have been investigated to reduce shoulder pain. Local anaesthetic techniques are part of the multimodal approach to postoperative pain management ${ }^{10}$ (Alkhamesi, 2007).

Our study demonstrates the intra-peritoneal instillation of bupivacaine reduces pain after LC significantly. It shows reduced incidence of both shoulder pain and postoperative nausea and vomiting. The total analgesic consumption was reduced significantly as compared to placebo.VAS scores were lower in group B (bupivacaine) than group A (placebo) during the overall estimated time and as well as the interval times of estimation. During the study no patients were excluded from the study because of uncontrolled pain or undesirable surgical outcomes such as delayed bowel movements and patient intolerance.

Pain is a highly personal experience which is whatever the experiencing person expresses and exist whenever the person appeals. The ambiguity of pain lies in that it is a subjective sensation or emotion and thorough objective observation of such is difficult. Because VAS scores are estimated by patients the accurate measurement is limited and objective estimation of pain could be deleterious. Narchi P et al. (1991) ${ }^{11}$ assessed the analgesic effect of intra-peritoneal local anaesthetics (0.5\% lignocaine with adrenaline and $0.125 \%$ bupivacaine with adrenaline) during day-case diagnostic laparoscopy. Both local anaesthetics were more effective in reducing postoperative shoulder pain than either control or saline. Analgesic requirements were greater in the non-treatment groups than in the local anaesthetic groups. They found this to be an efficient method of reducing the intensity of scapular pain. In our study we used $0.5 \%$ bupivacaine; we found reduction in both visceral pain and shoulder pain.

In the study by Schulte-Steinberg et al. (1995) ${ }^{12}$, interpleural bupivacaine $(0.25 \%)$ produces analgesia after laparoscopic cholecystectomy, and attributed the lack of effect of intraperitoneal injections to the small dose and to a rapid dilution within the peritoneal cavity. However, in our study, intraperitoneal bupivacaine produced significant postoperative analgesia which could be due to higher concentration of bupivacaine used by us. Further, Joris et al. (1995) ${ }^{4}$ reported that visceral pain accounts for the major discomfort experienced in early postoperative period whereas shoulder tip pain becomes the main complaint on the second day. 
Intraperitoneal bupivacaine did not significantly affect any of the different components of postoperative pain. Analgesic consumption was similar in the two groups. Intraperitoneal bupivacaine is not effective for treating any type of pain after laparoscopic cholecystectomy. However, in our study, intraperitoneal $0.5 \%$ bupivacaine significantly reduced postoperative pain. This could be due to higher concentration $(0.5 \%)$ of intraperitoneal bupivacaine used by us.

In the study of Tsimoyiannis et al. (1998) ${ }^{13}$ patients received either normal saline under the right hemi-diaphragm or bupivacaine $1.5 \mathrm{mg} / \mathrm{kg}$. They found that postoperative pain was significantly reduced in the bupivacaine group. Similarly, in our study intraperitoneal bupivacaine reduced the pain after laparoscopic cholecystectomy. Bhardwaj et al. (2002) ${ }^{14}$ reported that the VAS was significantly higher in group I (normal saline intraperitoneally) compared to group II (20 ml of $0.5 \%$ bupivacaine with 1:200,000 adrenaline) at 1st, 4th and 8th postoperative hour. Shoulder pain was not present in any of the patients in both the groups. The total number of patients requiring analgesics was higher for group I than group II. They found that intraperitoneal instillation of bupivacaine reduced good pain relief after laparoscopic cholecystectomy. In our study also, similar effects were found with bupivacaine.

Kucuk et al. (2007) ${ }^{15}$ compared the effect of intraperitoneal ropivacaine $(150 \mathrm{mg})$ and bupivacaine $(100 \mathrm{mg})$ in patients undergoing a laparoscopic cholecystectomy. They found that for preventing postoperative $100 \mathrm{mg}$ bupivacaine was found to be effective. In our study, bupivacaine $100 \mathrm{mg}$ also found to be effective.

\section{Conclusion}

We conclude that intraperitoneal instillation of local anaesthetic is an easy, cheap, and non-invasive method which provides good analgesia in the immediate postoperative period after laparoscopic surgery.

\section{References}

[1] Raetzell M, Maier C, Schroder D,Wulf H. Intraperitoneal application of bupivacaine during laparoscopic cholecystectomy - risk or benefit?AnesthAnalg 1995; 81: 967-972

[2] Michaloliakou C, Chung F, Sharma S.Preoperative multimodal analgesia facilitates recovery after ambulatory laparoscopic cholecystectomy.AnesthAnalg. 1996 Jan;82(1):44-51.

[3] Alexander JI. Pain after laparoscopy. Br J Anaesth 1997; 79:369-78.

[4] Joris J, Thiry E, Paris P, WeertsJ,Lamy M. Pain after laparoscopic cholecystectomy: characteristics and effect of intraperitoneal bupivacaine. AnesthAnalg 1995; 81: 379-384.

[5] Zmora O, Srolik-Dollberg O, BarZakai B, etal.Intraperitoneal bupivacaine does not attenuate pain followinglaparoscopic cholecystecromy. J SocLaparoendoscopic Surg 2000; 4:301-304.

[6] Helvacioglu A, Weis R. Operative laparoscopy and postoperative pain relief. FertilSteril 1992;57:548-52.

[7] Hilvering B, Draaisma WA, van der Bilt JD, Valk RM, Kofman KE, Consten EC.Randomized clinical trial of combined preincisional infiltration and intraperitoneal instillation of levobupivacaine for postoperative pain after laparoscopic cholecystectomy. Br J Surg. 2011 Jun;98(6):784-9

[8] AlexanderJi, Hull MGR. Abdominal pain after laproscopy: the value of a gas drain. Br J ObstetGynaecol 1987; 94:267-269.

[9] Bisgaard T, Klarskov B. Multiregional local anaesthetic infiltration during laparoscopic cholecystectomy in patients receiving prophylactic multimodal analgesea: a randomezed, double blinded,placebo controlled study. Anaes Anal 1999;89:1017-1024

[10] Alkhamesi NA, Peck DH, Lomax D, Darzi AW.Intra-peritoneal aerosolization of bupivacaine reduces post-operative pain in laparoscopic surgery: a randomized prospective controlled double-blinded clinical trial.SurgEndosc. 2007 Apr;21(4):602-6.

[11] Narchi P, Benhamou D, Fernandez H. Intraperitoneal local anaesthetic for shoulder pain after day case laparoscopy. Lancet 1991;338:1569-70.

[12] Schulte-Steinberg H, Weninger E, Jokisch D, et al. Intraperitonealversus interpleural morphine or bupivacaine for pain after laparoscopic cholecystectomy. Anesthesiology 1995;82:634-40.

[13] Tsimoyiannis EC, Glantzounis G, Lekkas ET, Siakas P, Jabarin M, Tzourou H.Intraperitoneal normal saline and bupivacaine infusion for reduction of postoperative pain after laparoscopic cholecystectomy.SurgLaparoscEndosc. 1998 Dec;8(6):416-20.

[14] Bhardwaj Neerja, Sharma Vikas, Chari Pramila. Intraperitoneal bupivacaine instillation for postoperative pain relief after laparoscopic cholecystectomy.Indian J. Anaesth. 2002; 46 (1) : 49-52.

[15] Kucuk C, Kadiogullari N, Canoler O, Savli S. A placebocontrolledcomparison of bupivacaine and ropivacaine instillationfor preventing postoperative pain after laparoscopic cholecystectomy.Surg Today. 2007;37:396-400.

Table-1: Basic characteristics of three groups

\begin{tabular}{|c|c|c|c|}
\hline Characteristics & $\begin{array}{c}\text { Group A } \\
(\mathbf{n}=75)\end{array}$ & $\begin{array}{c}\text { Group B } \\
(n=75)\end{array}$ & p-value \\
\hline $\begin{array}{l}\text { Age (yrs): } \\
\text { Mean } \pm \text { SD } \\
\text { Range (min-max) }\end{array}$ & $\begin{array}{c}39.80 \pm 9.07 \\
(20-50)\end{array}$ & $\begin{array}{c}38.96 \pm 9.56 \\
(20-50)\end{array}$ & 0.84 \\
\hline $\begin{array}{l}\text { Sex: } \\
\text { Males } \\
\text { Females } \\
\end{array}$ & $\begin{array}{l}30(40 \%) \\
45(60 \%)\end{array}$ & $\begin{array}{l}30(40 \%) \\
45(60 \%)\end{array}$ & 0.63 \\
\hline $\begin{array}{l}\text { ASA Physical Status: } \\
\text { Grade I } \\
\text { Grade II }\end{array}$ & $\begin{array}{l}54(72 \%) \\
21(28 \%)\end{array}$ & $\begin{array}{l}51(68 \%) \\
24(32 \%)\end{array}$ & 0.24 \\
\hline
\end{tabular}


The effect of intraperitoneal bupivacaine for post-operative pain management in patients undergoing

Table 2: Comparison of heart rate and blood pressure among the three groups

\begin{tabular}{|c|c|c|c|c|c|c|c|c|}
\hline \multirow[b]{2}{*}{ Time } & \multicolumn{2}{|c|}{ Heart rate } & \multicolumn{2}{|c|}{$\begin{array}{c}\text { Systolic blood } \\
\text { pressure }\end{array}$} & \multicolumn{2}{|c|}{$\begin{array}{c}\text { Diastolic blood } \\
\text { pressure }\end{array}$} & \multicolumn{2}{|c|}{ Mean blood pressure } \\
\hline & $\begin{array}{c}\text { Group A } \\
(n=75)\end{array}$ & Group B & $\begin{array}{l}\text { roup A } \\
(n=75)\end{array}$ & $\begin{array}{c}\text { Grou } \\
(\mathbf{n}=7\end{array}$ & $\begin{array}{c}\text { Group A } \\
(n=75)\end{array}$ & $\begin{array}{c}\text { Group } \\
\text { B } \\
(n=75)\end{array}$ & & \\
\hline $\mathrm{Ba}$ & & & $2 \pm 12$ & $\begin{array}{l}123.1 \\
.27\end{array}$ & 7 & $\begin{array}{l}77.32 \pm 7 . \\
18\end{array}$ & & $\begin{array}{l}37.72 \pm 8 . \\
56\end{array}$ \\
\hline \multicolumn{9}{|l|}{ Intra } \\
\hline $15 \mathrm{~m}$ & . & 0 & $\begin{array}{r}4.28 \pm 11 \\
.96\end{array}$ & & $\begin{array}{c}9.56 \pm 12 \\
.08\end{array}$ & $\begin{array}{c}79.64 \pm 8 . \\
36\end{array}$ & & $\begin{array}{c}8.16 \pm 9 . \\
23\end{array}$ \\
\hline 30min & $\begin{array}{r}85.40 \\
15\end{array}$ & 1 & $\begin{array}{r}122.96 \pm 11 \\
.88\end{array}$ & 121. & $\begin{array}{c}81.00 \pm 10 \\
.46\end{array}$ & $\begin{array}{l}79.52 \pm 5 . \\
\quad 46\end{array}$ & 1 & $\begin{array}{c}86.56 \pm 9 . \\
76\end{array}$ \\
\hline$m$ & $\begin{array}{r}84.60 \\
8 \\
\end{array}$ & 1( & $\begin{array}{r}122.40 \pm 14 \\
.32\end{array}$ & .4 & $\begin{array}{l}9.04 \pm 1 \\
.92\end{array}$ & $\begin{array}{l}9.56 \pm 5 . \\
40\end{array}$ & .80 & $\begin{array}{l}.20 \pm 8 . \\
73\end{array}$ \\
\hline $60 \mathrm{mi}$ & $\begin{array}{r}85.22 \\
85\end{array}$ & 7 & $\begin{array}{r}123.92 \pm 10 \\
.63\end{array}$ & $\begin{array}{r}121.2 \\
.0\end{array}$ & $\begin{array}{r}81.96= \\
.63\end{array}$ & $\begin{array}{c}78.96 \pm 7 . \\
28\end{array}$ & 1. & $\begin{array}{c}87.32 \pm 7 \\
38\end{array}$ \\
\hline $75 \mathrm{mi}$ & $\begin{array}{r}88.3 \\
.7\end{array}$ & $\begin{array}{r}80.7 \\
5\end{array}$ & $\begin{array}{r}124.64 \pm 11 \\
.71\end{array}$ & 121 & $\begin{array}{r}81.44 \\
.5\end{array}$ & $9.00 \pm 5$. & 12 & $\begin{array}{l}7.52 \pm 5 . \\
90\end{array}$ \\
\hline $90 \mathrm{~min}$ & $\begin{array}{c}84.48 \pm \\
48\end{array}$ & $\begin{array}{l}1.84 \pm 8 . \\
62\end{array}$ & $\begin{array}{r}121.80 \pm 10 \\
.71\end{array}$ & 120. & $\begin{array}{l}0.40 \pm 9 . \\
51\end{array}$ & $\begin{array}{c}80.36 \pm 6 . \\
12\end{array}$ & $89.44 \pm 9$ & $\begin{array}{c}90.56 \pm 9 . \\
07\end{array}$ \\
\hline \multicolumn{9}{|c|}{ rative } \\
\hline $15 \mathrm{~min}$ & 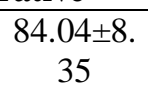 & Y & $\begin{array}{r} \pm 12 \\
.10\end{array}$ & . & 11 & $\begin{array}{l}8.08 \pm 6 . \\
42\end{array}$ & .8 & $\begin{array}{c}0.44 \pm 10 \\
.94\end{array}$ \\
\hline 30min & $\begin{array}{r}86.92 \\
39\end{array}$ & $\begin{array}{c}1.20 \pm 5 . \\
92\end{array}$ & $\begin{array}{r}124.12 \pm 10 \\
.28\end{array}$ & $\begin{array}{c}121.36 \pm 4 \\
.49\end{array}$ & $\begin{array}{c}79.24 \pm 11 \\
.53\end{array}$ & $\begin{array}{c}79.88 \pm 4 . \\
95\end{array}$ & $\begin{array}{c}91.88 \pm 8 \\
98\end{array}$ & $\begin{array}{c}87.68 \pm 8 \\
60\end{array}$ \\
\hline $1 \mathrm{hr}$ & $\begin{array}{r}83.88 \\
95 \\
\end{array}$ & $2.84 \pm 7$. & $\begin{array}{r}120.80 \pm 11 \\
.76\end{array}$ & 120 & $\begin{array}{c}78.00 \pm 11 \\
.59\end{array}$ & $\begin{array}{c}78.48 \pm 7 . \\
58\end{array}$ & $\begin{array}{l}8.68 \pm 10 \\
.18\end{array}$ & $\begin{array}{l}9.44 \pm 8 . \\
09\end{array}$ \\
\hline $2 \mathrm{hr}$ & $\begin{array}{c}83.32 \pm 8 \\
52\end{array}$ & $\begin{array}{c}82.56 \pm 6 . \\
82\end{array}$ & $\begin{array}{r}118.92 \pm 9 \\
82\end{array}$ & $\begin{array}{c}120.28 \pm 5 \\
.50\end{array}$ & $\begin{array}{c}76.08 \pm 11 \\
.28\end{array}$ & $\begin{array}{l}77.08 \pm 6 . \\
42\end{array}$ & $\begin{array}{l}7.20 \pm 9 . \\
84\end{array}$ & $\begin{array}{l}9.88 \pm 7 . \\
87\end{array}$ \\
\hline $4 \mathrm{hr}$ & $\begin{array}{c}83.32 \pm 8 \\
69\end{array}$ & $82.52 \pm 5$ & $\begin{array}{r}121.24 \pm 9 . \\
36\end{array}$ & $120.50 \pm 6$ & $80.08 \pm 10$ & $\begin{array}{c}77.56 \pm 5 . \\
53\end{array}$ & $\begin{array}{c}90.28 \pm 11 \\
.57\end{array}$ & $93.20 \pm 9$ \\
\hline $8 \mathrm{hr}$ & $85.60 \pm$ & $\begin{array}{c}84.36 \pm 7 \\
08\end{array}$ & $\begin{array}{r}121.36 \pm 8 \\
72\end{array}$ & $\begin{array}{c}124.16 \pm 7 \\
.42\end{array}$ & $\begin{array}{c}78.04 \pm 9 . \\
62\end{array}$ & $\begin{array}{c}80.12 \pm 7 . \\
28\end{array}$ & $\begin{array}{l}.00 \pm 10 \\
.12\end{array}$ & $\begin{array}{c}3.84 \pm 9 . \\
37\end{array}$ \\
\hline $12 \mathrm{~h}$ & $\begin{array}{c}85.80 \pm 7 \\
59\end{array}$ & $\begin{array}{c}82.28 \pm 7 \\
17\end{array}$ & $\begin{array}{r}123.24 \pm 9 . \\
21\end{array}$ & $\begin{array}{c}119.84 \pm 4 \\
.54\end{array}$ & $\begin{array}{c}79.84 \pm 9 . \\
21\end{array}$ & $\begin{array}{c}78.24 \pm 5 . \\
39\end{array}$ & $\begin{array}{c}92.36 \pm 10 \\
.07\end{array}$ & $\begin{array}{c}94.48 \pm 9 . \\
32\end{array}$ \\
\hline $24 \mathrm{hr}$ & $\begin{array}{c}85.68 \pm 7 \\
04\end{array}$ & $\begin{array}{c}85.72 \pm 6 . \\
86\end{array}$ & $\begin{array}{r}124.08 \pm 8 . \\
52\end{array}$ & $\begin{array}{c}122.36 \pm 5 \\
.69\end{array}$ & $\begin{array}{c}80.92 \pm 8 \\
61\end{array}$ & $\begin{array}{c}79.16 \pm 7 . \\
31\end{array}$ & $\begin{array}{c}92.44 \pm 10 \\
.45\end{array}$ & $\begin{array}{c}94.04 \pm 9 . \\
18\end{array}$ \\
\hline
\end{tabular}

Table-3: Comparison of $\mathrm{SpO}_{2}$ among the three groups

\begin{tabular}{|c|c|c|}
\hline Time & $\begin{array}{c}\underset{(n=75)}{\operatorname{Group} A} \\
\end{array}$ & $\begin{array}{c}\text { Group B } \\
(n=75)\end{array}$ \\
\hline Baseline & $99.56 \pm 0.65$ & $99.84 \pm 0.37$ \\
\hline \multicolumn{3}{|l|}{ Intra-operative } \\
\hline $15 \mathrm{~min}$ & $99.52 \pm 0.65$ & $99.56 \pm 0.51$ \\
\hline $30 \mathrm{~min}$ & $99.48 \pm 0.77$ & $99.88 \pm 0.33$ \\
\hline $45 \mathrm{~min}$ & $99.36 \pm 0.81$ & $99.76 \pm 0.44$ \\
\hline $60 \mathrm{~min}$ & $99.56 \pm 0.71$ & $99.84 \pm 0.37$ \\
\hline $75 \mathrm{mi}$ & $99.28 \pm 0.84$ & $99.76 \pm 0.44$ \\
\hline $90 \mathrm{~min}$ & $99.40 \pm 0.87$ & $99.72 \pm 0.46$ \\
\hline \multicolumn{3}{|l|}{ Post-operative } \\
\hline $15 \mathrm{~min}$ & $99.56 \pm 0.51$ & $99.84 \pm 0.37$ \\
\hline $30 \mathrm{~min}$ & $99.76 \pm 0.44$ & $98.56 \pm 0.17$ \\
\hline $1 \mathrm{hr}$ & $99.72 \pm 0.46$ & $99.92 \pm 0.28$ \\
\hline $2 \mathrm{hr}$ & $99.64 \pm 0.49$ & $99.76 \pm 0.44$ \\
\hline $4 \mathrm{hr}$ & $99.88 \pm 0.33$ & $99.84 \pm 0.37$ \\
\hline $8 \mathrm{hr}$ & $99.72 \pm 0.54$ & $99.84 \pm 0.37$ \\
\hline $12 \mathrm{hr}$ & $99.80 \pm 0.41$ & $99.84 \pm 0.37$ \\
\hline $24 \mathrm{hr}$ & $99.72 \pm 0.61$ & $99.96 \pm 0.20$ \\
\hline
\end{tabular}


The effect of intraperitoneal bupivacaine for post-operative pain management in patients undergoing

Table-4: Comparison of Rescue analgesia time among groups

\begin{tabular}{|l|c|c|}
\hline Rescue analgesia at time (min) & $\begin{array}{c}\text { Group A } \\
(\mathbf{n = 7 5})\end{array}$ & $\begin{array}{c}\text { Group B } \\
(\mathbf{n = 7 5})\end{array}$ \\
\hline 1ST DOSE & $\begin{array}{c}24.60 \pm 10.50 \\
(75)\end{array}$ & $427.20 \pm 125.28(75)$ \\
\hline 2ND DOSE & $345.60 \pm 156.15(75)$ & $1344.00 \pm 268.33(75)$ \\
\hline 3RD DOSE & $912.00 \pm 415.69(75)$ & $\begin{array}{c}1440.00 \pm 0.00 \\
(9)\end{array}$ \\
\hline 4TH DOSE & $1215.00 \pm 344.67(48)$ & NIL \\
\hline 5TH DOSE & $\begin{array}{c}1440.00 \pm 0.00 \\
(15)\end{array}$ & NIL \\
\hline
\end{tabular}

Numbers in parenthesis indicates no. of subjects

Table-5: Adverse events summary of three groups

\begin{tabular}{|l|c|c|c|}
\hline Complications & $\begin{array}{c}\text { Group A } \\
(\mathbf{n = 5 0 )}\end{array}$ & $\begin{array}{c}\text { Group B } \\
(\mathbf{n = 5 0 )}\end{array}$ & p-value \\
\hline Pruritus & $3(4 \%)$ & $0(0.0)$ & 0.36 \\
\hline Emetic symptoms & $51(68 \%)$ & $15(20 \%)$ & $0.002^{*}$ \\
\hline Hypotension & $0(0.0 \%)$ & $0(0.0)$ & NA \\
\hline Bradycardia & $0(0.0 \%)$ & $0(0.0)$ & NA \\
\hline Shoulder pain & $66(92 \%)$ & $12(16 \%)$ & $\mathrm{p}<0.0001^{*}$ \\
\hline Sedation & $0(0.0 \%)$ & $0(0.0 \%)$ & NA \\
\hline
\end{tabular}

*Significant, NA- not applicable
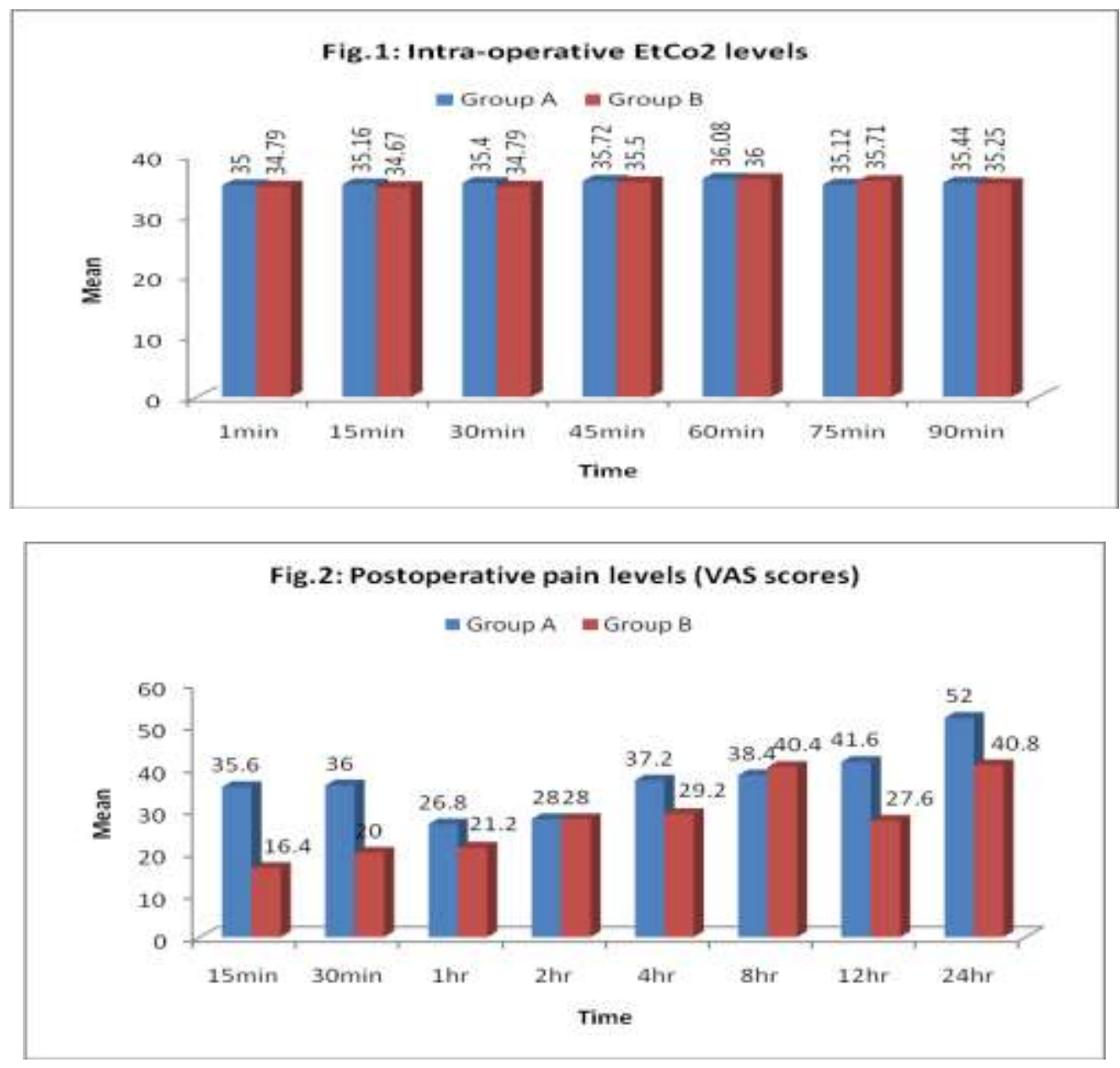